\title{
Current Obstacles of Business Development in Uzbekistan
}

\author{
Markhabo Saidova (Tashkent State University of Economics, Uzbekistan)
}

\begin{abstract}
This article refers to the theoretical and practical aspects of business, its development paths and strategy selection in Uzbek economy, the statistical analyses through methods of observation, collection of statistical data, classification, tabulation; and also diagrams and graphs frequently used in presenting data, dynamic changes, comparison and prognosis of indicators of the development of business, including the ways of improvement of private sector through solve the problems in the formation of economy as well as the perspectives of development of business in Uzbekistan. There are also given econometric modeling and forecasting of business development in GDP through analytical method in dynamic lines, OLS method taking into account the share of business in the number of employed in the volume of production of agricultural products, exports of the Republic of Uzbekistan.
\end{abstract}

\section{Introduction}

In today's highly competitive world, we cannot imagine economic development of country without business which is considered to be one of the main sectors as fast growing economy and improving living standards in national economy. Through developing of these sectors new jobs are created, productivity and competitiveness are increased, poverty are alleviated and societal goals are achieved, in particular by helping specific population groups to help themselves.

Business plays a crucial role in the formation and development of Uzbek economy. Since its independence the Republic of Uzbekistan, which is a doubly landlocked country conducted enormous economic changes. Economic reform has been gradually increased throughout many areas, such as business. As stressed by The First President of the Republic of Uzbekistan I.A.Karimov "Measures to improve the business environment and create more favorable conditions for the development of small business and private entrepreneurship deserve all kind of support" (I.A.Karimov,2015).

There are many different opinions to open the meaning of business. One of them is business is one which is independently owned and operated and not dominant in its field of operation. The intricacy of entrepreneurship makes it impossible to apprehend the totality of entrepreneurship with an idea; for that reason, I propose the following definition of entrepreneurship: "The entrepreneur has an owner or acting function, a risk and uncertainty bearing function, as well as, an innovation function."

There are some issues cause most business failures in Uzbekistan, as developed countries, they are: poor operations management, lack of experience, poor financial management, over-investing in fixed assets, poor credit practices, failure to plan, inappropriate location, lack of inventory control and others.

As it's said above, business plays a distinctive and irreplaceable role in the development of the economy in Uzbekistan. Through developing of these sectors is provided with creating new jobs, increasing productivity and competitiveness, alleviating poverty and achieving societal goals. Uzbek economy operates two types of enterprises, which are large and small enterprises, as well as the activities depend on personal and family labor. The condition to run a business in Uzbekistan has been implemented through the Law of the Republic of Uzbekistan "On family business", "On the introduction of amendments and additions" in the Law of the Republic of Uzbekistan, "On guarantees of free entrepreneurial activity " and they are designed to further facilitate the development of business.

According to the Decree of the President of the republic of Uzbekistan the law "On measures to further stimulation of business development" from April 9, 1998, the subjects of Business divided into three parts:

(1) Individual business-is physical person without legal entity, juridical person;

(2) Micro firm- employing 20 people or fewer people in production, 10 people or fewer in services, 5 people or fewer in trade;

(3) Small business. A firm was considered "small" for the purposes of tax collection if the number of employees did not exceed an officially established limit of 200 people (to July 1, 2014 was 100 people) in heavy industry and construction, 25 in Research and science, 20 in other areas of production, 10 in trade and services.

\section{Methodology and Results}

\subsection{Data}

The statistical data has been taken from the official website and reports of The State Committee of Uzbekistan. All used data in this article describe the share of business in GDP, in the number of employed, in the volume of production of agricultural products and exports of the Republic of Uzbekistan during the period 2000-2016. 


\subsection{Descriptive Statistics}

As the matter of fact, according to the governmental report, the GDP of the Republic of Uzbekistan for 2017 in current prices amounted to 249136.4 billion sums and grew by $5.3 \%$ relative to the corresponding period of 2016 . The index-deflator of GDP in relation to the prices of 2016 amounted to $118.9 \%$.

At the end of 2017, GDP per capita amounted to 7.092 million sums, which is $3.6 \%$ more than last year. The largest contribution to GDP growth was made by the services sector, which grew by $6.9 \%$ compared to the previous year. Of this, trade, including accommodation and food services, grew by $3.9 \%$, transportation and storage, information and communication - by $8.9 \%$ and other services - by $7.3 \%$.

The added value of the industry showed an increase of $4.6 \%$, which was $26.7 \%$ in the GDP structure. A positive contribution to GDP growth from industrial production is estimated at $1.1 \mathrm{pp}$. Growth in the industry as a whole is ensured by the growth of the added value of the mining industry and quarrying (114.6\%) and manufacturing $(102.8 \%)$.

As a result of ongoing large-scale construction of multi-apartment residential buildings, individual housing for standard projects, engineering and transport communications, social infrastructure facilities, etc., the increase in the volume of construction work was 5.6\%. In the structure of GDP, the share of construction amounted to $6.8 \%$. A positive contribution to GDP growth from the construction sector is estimated at $0.4 \mathrm{pp}$.

It is admitted that, the share of business in GDP is increasing year by year. As you can see below, the bar chart represents growing trend of share of business development in percent from 2000 to 2016 .

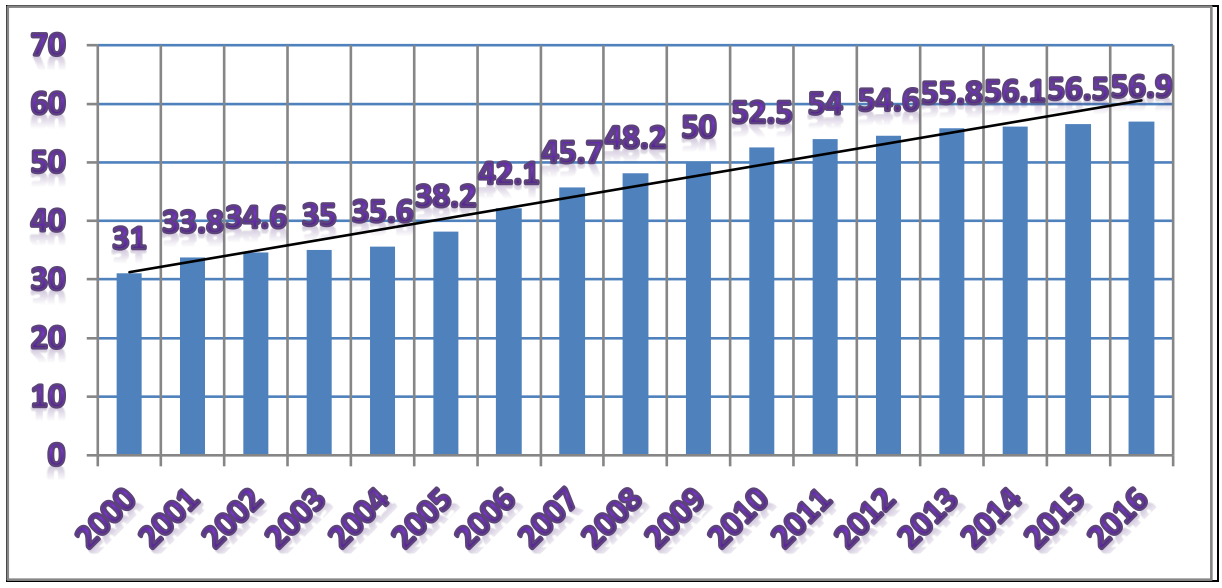

Graph 1. The Share of Business in 2010-2016 GDP in Uzbekistan (in percent) Source: The data are taken from the official website of "The State Committee of the Republic of Uzbekistan on Statistics"

\subsection{OLS Model to Test the Significances of the Relationships of the Share of Business in Uzbekistan}

The main aim of this paper is creating appropriate model and explain the meaning of the relationships. In this way taking into account specific features of our country I prefer to present two models. The former is ordinary least squares model, the latter is analytical method to prognosis for perspective data.

OLS model is also found appropriate to the business development in Uzbekistan. Here to change the share of business in GDP, the share of business in the number of employed, in the volume of production of agricultural products and exports are affected.

\begin{tabular}{r|crc} 
Source & SS & df & MS \\
\hline $\begin{array}{r}\text { Model } \\
\text { Residual }\end{array}$ & 1381.40638 & 2 & 690.703189 \\
\hline Total & 1441.41529 & 16 & 90.0884559
\end{tabular}

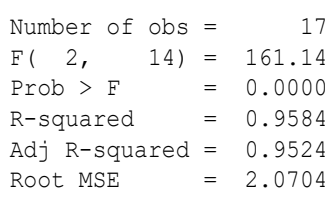

\begin{tabular}{r|rrrrrr}
\hline A & Coef. & Std. Err. & $t$ & P $>|t|$ & [95\% Conf. Interval] \\
\hline B & .7053432 & .0788269 & 8.95 & 0.000 & .5362764 & .87441 \\
D & .3849834 & .1106778 & 3.48 & 0.004 & .1476031 & .6223637 \\
_cons & -7.808183 & 4.328464 & -1.80 & 0.093 & -17.09181 & 1.475449
\end{tabular}

Table 1. OLS Regression Results of the Model for the Development of Business in Uzbekistan.

Note: The results are calculated with STATA 13.

From this Table 1 we can see that all regression coefficients are statistically significant, except the share of business in the volume of production of agricultural products. In further we use analytical method in dynamic lines to predict future events. 


\subsection{Analytical Method About Long-Range Prognosis of Business Development in Uzbekistan}

A prediction is a statement about a risk. It is often based upon experience or knowledge and it can be useful to assist in making decisions about possible developments. Howard H. Stevenson writes that prediction in business is at least two things: important and hard.(Howard H. Stevenson,2012)

We know, through analytical method in dynamic lines it can be predicted future events. Necessary information is given below:

\begin{tabular}{|c|c|c|c|c|c|}
\hline Years & $Y i$ & $t$ & $t 2$ & $Y{ }^{*} t$ & $Y t$ \\
\hline 2010 & 52,5 & -3 & 9 & $-157,5$ & 53,021 \\
\hline 2011 & 54,0 & -2 & 4 & $-108,0$ & 53,664 \\
\hline 2012 & 54,6 & -1 & 1 & $-54,6$ & 54,307 \\
\hline 2013 & 55,8 & 0 & 0 & 55,8 & 55,593 \\
\hline 2014 & 56,1 & 1 & 1 & 112,2 & 56,236 \\
\hline 2015 & 56,5 & 2 & 4 & 170,1 & 56,879 \\
\hline 2016 & 56,9 & 3 & 9 & 170,7 & 56,985 \\
\hline$\sum$ & 329,7 & & & & 329,7 \\
\hline
\end{tabular}

Table 2. Results Theoretical Aspects of Business Share in GDP for Observing Period Source: The Data Are Taken from the Official Website of "The State Committee of the Republic of Uzbekistan on Statistics"

In order to use analytical method, we need right linear equation. Here its mathematical formula:

In this, t-periods; $\mathrm{a}_{0}$ and $\mathrm{a}_{1}$

$$
\bar{Y}_{t}=\mathbf{a}_{0}+\mathbf{a}_{1} \mathbf{t}
$$

$$
\left\{\begin{array}{l}
\mathrm{a}_{0} \mathrm{n}+\mathrm{a}_{1} \sum \mathrm{t}=\sum \mathrm{y} \\
\mathrm{a}_{0} \sum \mathrm{t}-\mathrm{a}_{1} \sum \mathrm{t}^{2}=\sum \mathrm{yt}
\end{array}\right.
$$

Where, y-real degree of lines; and $n$-the number of degree.

$$
\mathrm{a}_{0}=\overline{\mathrm{y}}-\mathrm{a}_{1} \mathrm{t} \quad \text { and } \quad \mathrm{a}_{0}=\frac{\Sigma y}{\mathrm{n}}-\mathrm{a}_{1} \frac{\Sigma \mathrm{t}}{\mathrm{n}} \text {, after that } \mathrm{a} 0=(\mathrm{n} \Sigma \mathrm{yt}-\Sigma \mathrm{t} \Sigma \mathrm{y}) /(\mathrm{n} \Sigma \mathrm{t} 2-(\Sigma \mathrm{t}) 2)
$$

If $\sum \mathrm{t}=0$, then the equation above can be in that manner:

$$
\left\{\begin{array}{l}
\mathrm{a}_{0} \mathrm{n}=\sum \mathrm{y} \\
\mathrm{a}_{1} \sum \mathrm{t}^{2}=\sum \mathrm{yt}
\end{array}\right.
$$

First of all, it is needed to be identified $\mathrm{a}_{0}$ and $\mathrm{a}_{1}$; for that purpose, we have to calculate $\Sigma \mathrm{y}, \sum \mathrm{t}^{2}, \sum \mathrm{yt}$. According

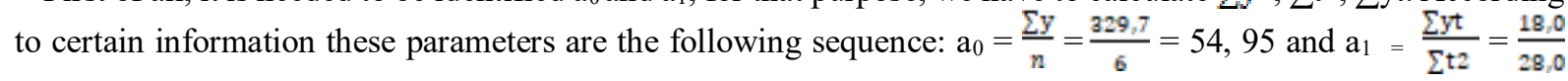
$=0,6$

To measure tendency of business I decided to use analytical method, which is one of the main methods to analyze economic changes in dynamic lines in statistics. In this example, analytical method about long-range prognosis of business development in Uzbekistan characterized by the following graph and it is predicted through zoom lines how recent economic trend may play out over the next few decades:

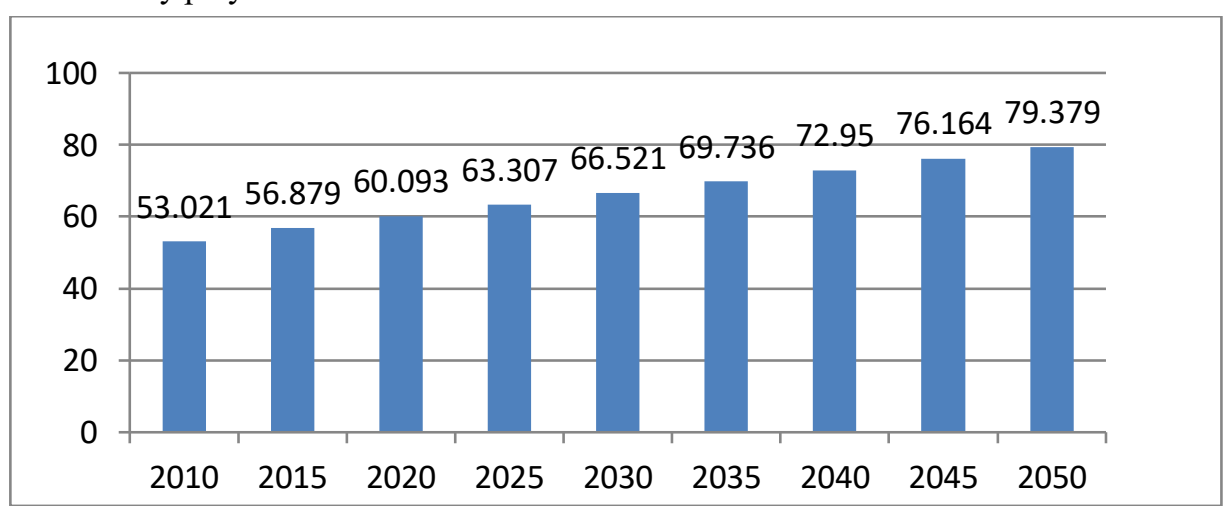

Graph 2. The Prognosis of Business Share in Gross Domestic Product in Uzbekistan

Note: Calculated by author through using information Business in Uzbekistan. Statistical Bulletin. Tashkent 2016

The bar chart illustrates the percentage of business in GDP in Uzbekistan from 2010 until 2050. It shows both present and future trend. Over the following five years, the share of business increased slightly from 53,0 per cent in 2010 to 56,8 per cent in 2015 . As can be seen, every five year the growth rate has raised three or four per cent and the share is expected to go up modestly. Between 2015 and 2050, it is also projected to raise, but more steadily and it is predicted to reach more than three quarters in 2050 and then it will soar gradually. 


\section{Conclusion}

Business more flexible and can adapt quickly to changes in demand, the situation on the global and regional markets, timely respond to their challenges, because it's compact in form, has a mobility and speed in decisionmaking and it's receptive to innovation. Creating and develop business do not require large expenditures and capital investments, which allows faster and easier to carry out modernization, technical and technological equipment, develop new products, constantly updating its range and provide competitiveness. The higher stability of this sector compared with large enterprises to the challenges and consequences of the global financial and economic crisis. Business are not only a source of income, but also opportunity to disclosure the creative and intellectual abilities of people. This scope allows everyone to show their individual talents and capabilities, thereby forming a new layer of people - enthusiastic, enterprising and prone to self-employment who can achieve the goal.

Principles of incentives to ensure the development of small business and private entrepreneurship are the provision of tax incentives, the use of a simplified tax system, preferential loans, reducing the frequency and timing of tax and accounting in government tax and statistical authorities, ways to reduce the frequency of tax and other inspections.

As stressed by the President, "We should be aware that what has been achieved so far is just the beginning of the long path that the country has chosen: to become a modern, developed, democratic country; to ensure a decent quality of life for the people and for future generations; and to achieve a strong reputation in the international community (I.A.Karimov, 2016).

Opportunities of various strata of the population in taking advantage of benefits of economic growth also directly depend on infrastructure conditions. Infrastructure services are not only the major consumer benefits but also are means for increase of labour productivity and improvement of market access. Both functions of infrastructure support of economic growth and expansion of its facilities- has a great importance for overcoming poverty, accumulating human capital, and increasing the welfare of the country.

Despite all these achievements, according to some sources, serious problems and misbalances, attributes of which can be found practically in all sectors and segments of the given sector of the economy, are maintained and being aggravated in social and economic infrastructure of the country.

Taking into account national peculiarities and spiritual values of the republic, entrepreneurship has a special social significance. Social efficiency reflects the degree of achievement of the social dimensions of entrepreneurship. In this case brings to the fore the question of how data with limited resources to best meet the needs of staff entrepreneurial structures (micro level) and all members of society (macro level).

Recommendations will be in the further development of business in Uzbekistan in order to tackle the problems:

Reduction of government intervention and regulatory authorities in the financial and economic activities of businesses; Creation of maximum favorable conditions, privileges and preferences on tax and other payments for business, improvement and standardization of the reporting system and the mechanism of delivery of reports in the financial, tax and statistical authorities; Broad involvement and direction for the development of business of foreign investment, especially concessional loans from international financial institutions and private equity; Further development of the information management system and advice to business, as well as in matters of training, retraining and skills development; Expand opportunities for small businesses bank loans, raw materials.

Needless to say, special initiatives to reduce burdens and support regulatory compliance of business should be balanced against other concerns. Business have been put forward and originally realized in industrially developed countries, but soon was picked up also in developing countries, which have experienced urgent need for expansion and modernization of infrastructure. The most important features are the ability of small businesses to accelerate the development of investment and high turnover of working capital. Another characteristic of this sector is an active innovation and accelerate the development of various sectors of the economy in all sectors of the Uzbek economy. 


\section{Appendix 1}

\begin{tabular}{|l|l|l|l|l|}
\hline Years & $\begin{array}{l}\text { The share of } \\
\text { business in } \\
\text { GDP } \\
\text { (in percent) }\end{array}$ & $\begin{array}{l}\text { The share of business } \\
\text { in the number of } \\
\text { employed } \\
\text { (in percent) }\end{array}$ & $\begin{array}{l}\text { The share of business in the volume } \\
\text { of production of agricultural } \\
\text { products } \\
\text { (in percent) }\end{array}$ & $\begin{array}{l}\text { The share of } \\
\text { business in } \\
\text { exports } \\
\text { in percent) }\end{array}$ \\
\hline 2000 & 31,0 & 49,7 & 73,6 & 10,2 \\
\hline 2001 & 33,8 & 51,8 & 74,5 & 9,3 \\
\hline 2002 & 34,6 & 53,5 & 74,9 & 7,5 \\
\hline 2003 & 35,0 & 56,7 & 78,1 & 6,9 \\
\hline 2004 & 35,6 & 60,3 & 81,1 & 7,3 \\
\hline 2005 & 38,2 & 64,8 & 85,7 & 6,0 \\
\hline 2006 & 42,1 & 69,1 & 94,0 & 10,7 \\
\hline 2007 & 45,7 & 72,1 & 97,6 & 14,8 \\
\hline 2008 & 48,2 & 73,1 & 97,7 & 12,3 \\
\hline 2009 & 50,0 & 73,9 & 97,8 & 14,6 \\
\hline 2010 & 52,5 & 74,3 & 97,8 & 13,6 \\
\hline 2011 & 54,0 & 75,1 & 97,7 & 18,8 \\
\hline 2012 & 54,6 & 75,6 & 97,8 & 15,7 \\
\hline 2013 & 55,8 & 76,7 & 98,0 & 18,0 \\
\hline 2014 & 56,1 & 77,6 & 98,3 & 26,0 \\
\hline 2015 & 56,7 & 77,9 & 98,4 & 26,9 \\
\hline 2016 & 56,9 & 78,1 & 98,5 & 28,5 \\
\hline
\end{tabular}

\section{References}

- Annual Statistical Report of Uzbekistan, 2015. Tashkent.

- Karimov, 2015. "The results of socio-economic development of the country in 2014 and main priorities of economic program for 2015", In order to make more opportunities for development of private property and private enterprise through the implementation of the indigenous structural change in economy, a consistent continuation of the processes of modernization and diversification is our priority, 7, p. 12.

- Small business in Uzbekistan, 2015.Statistical Bulletin. Tashkent. 16 p.

- The Ministry of economy of the Republic of Uzbekistan has published a report on the results of socioeconomic development of the country in 2015 and the most important priorities of economic program for 2016, January 15, 2016. The year 2015 observed the continuation of active work on providing the reliable protection to private property, small business and private entrepreneurship, the removal of barriers to their rapid development, Khalk suzi,Tashkent. 